\title{
Effect of dehydroepiandrosterone sulfate on interleukin-8 receptor during cervical ripening
}

\author{
Naohiro Kanayama, Emad El Maradny, Junko Goto and Toshihiko Terao \\ Department of Obstetrics and Gynecology, Hamamatsu University School of Medicine, 3600 Handa-Cho, Hamamatsu 431-31, Japan \\ (Correspondence should be addressed to N Kanayama)
}

\begin{abstract}
We investigated the effects of dehydroepiandrosterone sulfate (DHA-S) on the production of interleukin-8 (IL-8) and expression of the interleukin-8 receptor (IL-8 R) in human cervical tissue. DHA-S increased the levels of IL-8 in cultured human cervical fibroblasts and in the supernatant in a timeand dose-dependent manner. DHA-S induced IL-8 and IL-8 R expression in human cervical fibroblasts and human pregnant cervical tissue at term in a dose-dependent manner. In addition, it induced the expression of IL-8 $\mathrm{R}$ in an explant culture of human cervical tissue and cultured human cervical fibroblasts in a time- and dose-dependent manner. However, dehydroepiandrosterone (DHA) only slightly induced the production of IL-8 and the expression of IL-8 R in the same cells and tissue. These results suggest that DHA-S up-regulates the autocrine system of IL- 8 through the expression of IL-8 R.
\end{abstract}

European Journal of Endocrinology 138 587-593

\section{Introduction}

Cervical ripening is an essential step for normal parturition. The uterine cervix is mainly made up of collagen bundles embedded in a ground matrix containing glycosaminoglycans (1). Marked biochemical changes in cervical tissue are observed during dilatation at term (2). Collagenase and elastase enzymes are believed to play a role in collagen metabolism during ripening $(3,4)$. It is suggested that during pregnancy collagenolytic changes in cervical connective tissue are hormonally controlled $(5,6)$. Dehydroepiandrosterone sulfate (DHA-S) is thought to be involved directly or indirectly in cervical ripening (7). Tahara et al. reported that high concentrations of estrogen and DHA-S are found in the ripened cervix (8). Intravenous injection of DHA-S is commonly used in Japan to induce cervical ripening in patients with an unfavorable cervix late in pregnancy. Recently, local application of vaginal DHA-S suppositories has been very effective in inducing ripening. DHA-S, which is the main precursor of estrogen biosynthesis in the placenta (9), is found to promote interstitial collagenase and gelatinase production in tissue cultures (10). Injection of DHA-S leads to increased estrogen in portiovaginalis (11). However, $\mathrm{E}_{2}$ is found to suppress the production of collagenase in rabbit cervical cultures and rat uterus $(12,13)$. Accordingly, the mechanism of the action of DHA-S cannot be explained by its conversion to estrogen. Junqueira et al. (14) and Rath et al. (15) have shown that neutrophil invasion of the cervix occurs in labor. Neutrophils contain three proteases that are capable of degrading the collagenous content of the cervical tissue: collagenase, elastase and gelatinase (16). Neutrophilderived rather than endogenous collagenolytic enzymes are thought to be involved in the process of cervical ripening (17). Interleukin-8 (IL-8), which mediates the transendothelial migration of neutrophils to the site of inflammation, is a newly discovered cytokine with a potent neutrophil chemotactic effect (18). IL-8 also activates neutrophils leading to the release of their granule content that includes collagenase, elastase and gelatinase (19). Effects of IL-8 are mediated by binding to two types of specific high affinity receptors, I and II. Exogenous application of IL- 8 to the cervix in rabbits is found to induce ripening (20). The uterine cervix in humans and rabbits produces large amounts of IL-8, especially late in pregnancy $(21,22)$. The production of IL-8 in the cervix is suggested to be influenced by steroid hormones. Progesterone is reported to suppress IL-8 production in the rabbit uterine cervix (23). The progesterone level is markedly decreased in women who begin labor within $24 \mathrm{~h}$ after injection of DHA-S (11). Since the effects of IL- 8 are modulated at the receptor level, IL-8 receptors (IL-8 R) may be an important target of steroid hormones in the cervix. We assumed that DHA-S may play a role in the effect of IL-8 and its receptors on the cervix. Accordingly, the aim of this research was to study the effect of DHA-S on IL-8 and its receptor in the pregnant cervix. 


\section{Materials and methods}

\section{Cell culture}

Cervical biopsy was collected from four patients at term (38-40 weeks) during elective Cesarean section. This tissue was cut into small pieces, placed in a 24-well plastic dish, and cultured in modified Eagle's medium (MEM) containing $10 \%$ fetal calf serum in $\mathrm{CO}_{2}$ at $37^{\circ} \mathrm{C}$. When the fibroblasts were growing rapidly, the tissue was removed and culture was continued to confluence. Each well was treated with different doses of DHA-S $(0.01,0.1 \mathrm{mg} / \mathrm{ml})$ and DHA $(0.01,0.1 \mathrm{mg} / \mathrm{ml})$, in $\mathrm{CO}_{2}$ at $37^{\circ} \mathrm{C}$ for $3-24 \mathrm{~h}$. The supernatants were then collected and their IL-8 levels were measured by ELISA. The wells were washed twice with phosphate-buffered saline (PBS), and treated with $400 \mathrm{ml}$ 1\% Triton X-100/ PBS for $1 \mathrm{~h}$. The resulting lysates were centrifuged at $3000 \mathrm{~g}$ for $10 \mathrm{~min}$, and the intracellular IL-8 in the supernatants was measured by ELISA. IL-8 levels were measured with a commercially available ELISA kit (Amersham, Tokyo, Japan) by the quantitative immunometric, sandwich enzyme immunoassay technique. Exact concentrations of IL-8 were calculated from a standard curve according to the manufacturer's directions. The protein concentration of the cells was measured by ANASOLV TP (Daiichi Pure Chemicals Co., Tokyo, Japan). The concentrations of IL-8 were normalized using these results.

\section{Immunocytochemistry}

The human cervical fibroblasts described above were cultured in chamber slides (LAB-TEK, Nalge Nunc International, Naperville, IL, USA). After the cells grew to occupy about $70 \%$ of the chamber, each well was treated with different doses of DHA-S $(0.01,0.1 \mathrm{mg} / \mathrm{ml})$ in $\mathrm{CO}_{2}$ at $37^{\circ} \mathrm{C}$ for $24 \mathrm{~h}$ after which immunocytochemistry of the cells was performed. The medium was removed and washed three times with $\mathrm{PBS}, \mathrm{pH}$ 7.3. The cells were fixed with 3\% paraformaldehyde solution for $10 \mathrm{~min}$ at $23^{\circ} \mathrm{C}$, and washed again with PBS. The chambers were washed twice in PBS ( $\mathrm{pH} 7.5)$ followed by fixation in methanol and hydrogen peroxide. After washing, sections were blocked with bovine serum albumin (BSA-PBS 2\%) for $20 \mathrm{~min}$. Polyclonal antibodies to human IL-8 receptor type I were used to treat the sections (diluted 1:60) overnight at $4{ }^{\circ} \mathrm{C}$. After washing five times in PBS, the sections were incubated with the second antibody (goat anti-rabbit IgG antibody; DAKO, Kyoto, Japan) at a concentration of 1:200 for $3 \mathrm{~h}$ at room temperature. Avidin (DAKO, Kyto, Japan) was added at a concentration of 1:1000 for $1 \mathrm{~h}$. Finally, slides were reacted with 3\% 3-amino-9-ethyl carbazol substrate ( $5 \mathrm{~min}$ at $23^{\circ} \mathrm{C}$, DAKO) and were counterstained with hematoxylin. Negative control sections were subjected to the same methods, except that primary antibodies were replaced with Tris-buffered saline solution.

\section{Immunohistochemistry}

Written consent was obtained from all patients in the study. Cervical biopsies were collected from four patients at term (38-40 weeks) during elective Cesarean section. Each biopsy (approximately $5 \mathrm{~g}$ tissue) was divided into six parts and used for tissue cultures by incubation with MEM in $\mathrm{CO}_{2}$ at $37^{\circ} \mathrm{C}$. Pieces of cervical tissues were treated with different doses of DHA-S (0, 0.1 and $1 \mathrm{mg} / \mathrm{ml})$ and of DHA (0, 0.1 and $1 \mathrm{mg} / \mathrm{ml})$. Fresh

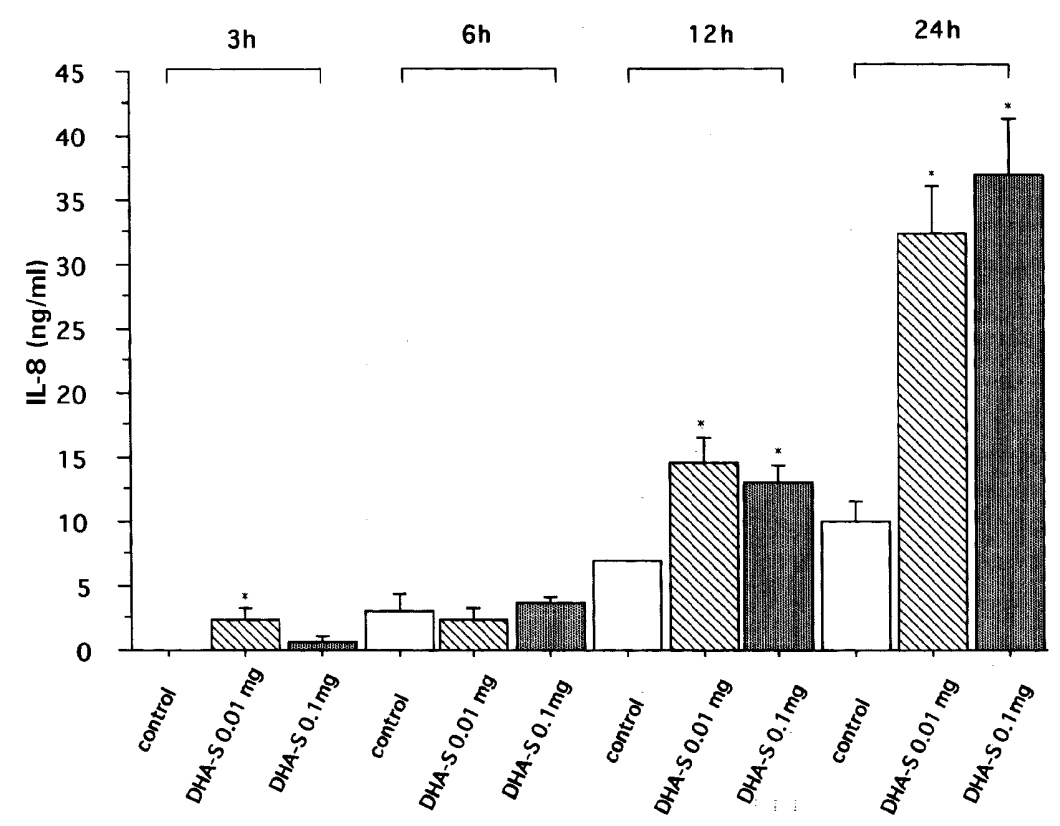

Figure $1 \mathrm{IL}-8$ concentration in supernatants of human cervical fibroblasts at different times after DHA-S treatment. Open bars, no DHA-S; hatched bars, DHA-S $(0.01 \mathrm{mg} / \mathrm{ml})$; shaded bars, DHA-S $(0.1 \mathrm{mg} / \mathrm{ml}) .{ }^{*} P<0.01$ compared with respective control. 


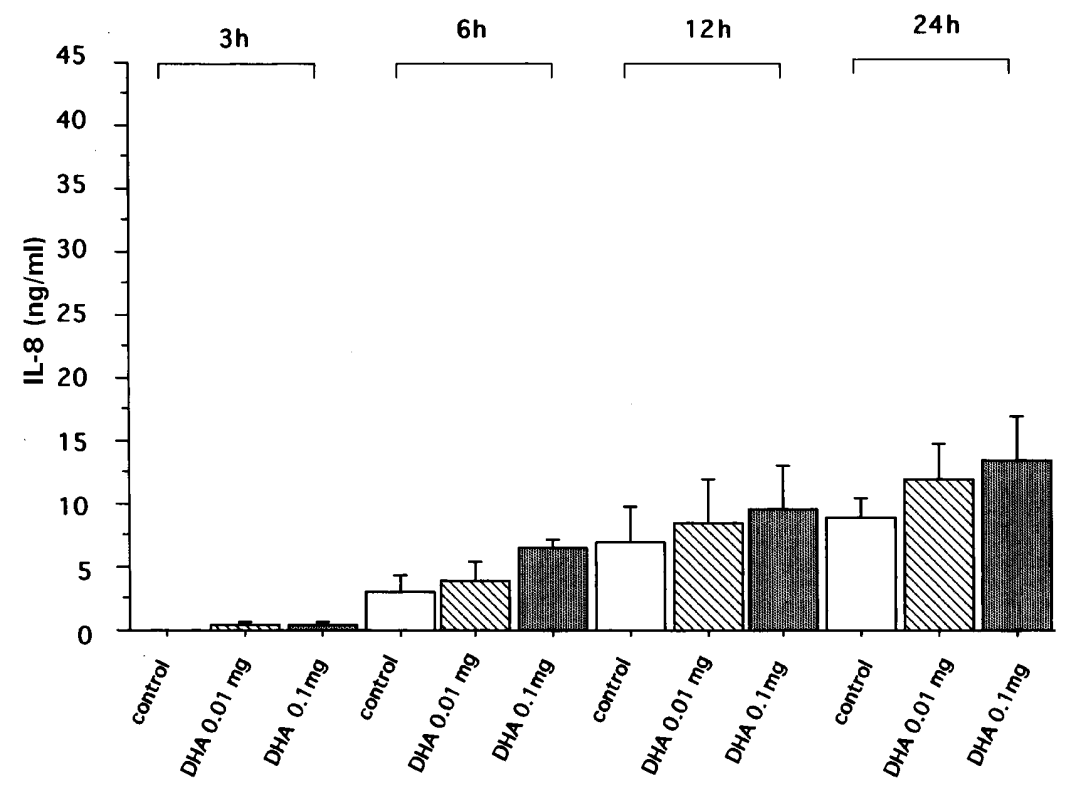

Figure $2 \mathrm{IL}-8$ concentration in supernatants of human cervical fibroblasts at different times after DHA treatment. Open bars, no DHA; hatched bars, DHA $(0.01 \mathrm{mg} / \mathrm{ml})$; shaded bars, DHA $(0.1 \mathrm{mg} / \mathrm{ml})$. frozen sections were prepared and immunohistochemical staining for IL-8 and IL- 8 receptor type I in cervical tissues and cervical cells cultured with DHA-S and control groups was performed using the streptavidin-biotin complex-peroxidase kit (DAKO USA). First, antibody (specific anti-IL-8 receptor antibody type I) was prepared by immunizing rabbits with glutathione-S-transferase fused with the $\mathrm{NH}_{2}$ terminal domain of each type of $\mathrm{IL}-8$ receptor. Polyclonal antibodies that specifically recognize the $\mathrm{NH}_{2}$-terminal domain of IL-8 receptors were prepared. Anti-IL-8 receptor antibodies were kindly provided by Professor Koji Matsushima, Kanazawa University, Japan. Control sections were subjected to the same methods, except that primary antibodies were replaced with Tris-buffered saline solution.

\section{Statistical analysis}

All data are shown as means \pm S.D. and Student's $t$-test was used for analysis of these data.

\section{Results}

\section{Effects of DHA-S and DHA on IL-8 production}

We measured the levels of IL- 8 in conditioned media of cervical fibroblasts $0,3,6,12$ and $24 \mathrm{~h}$ after

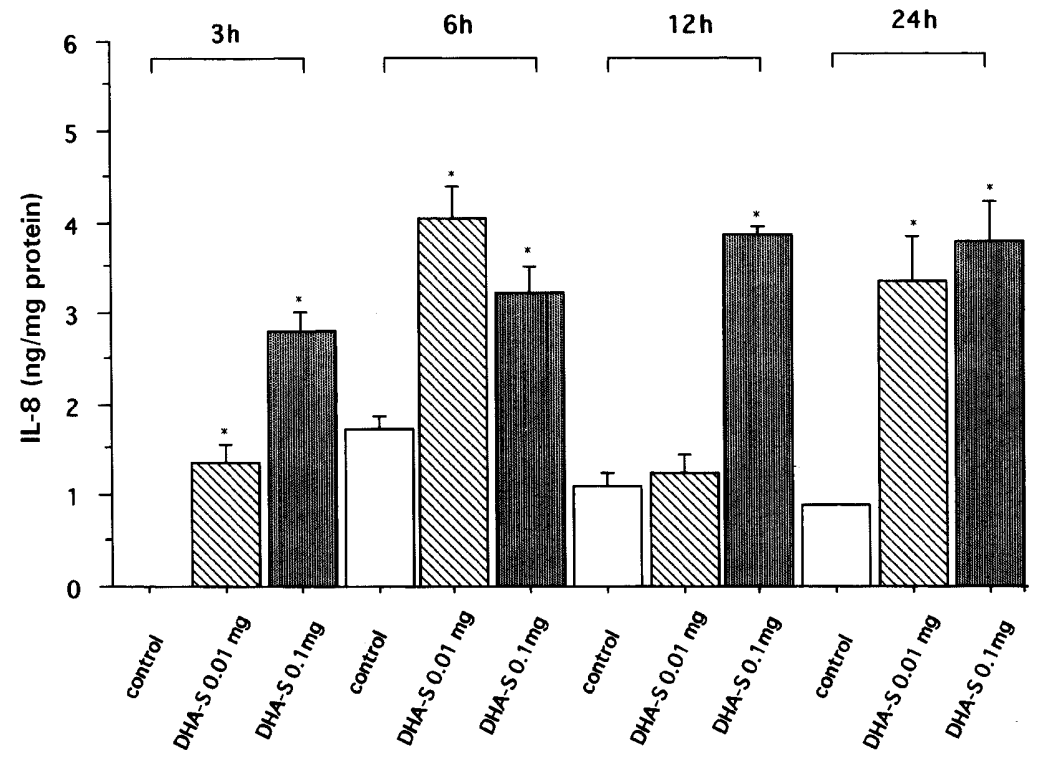

Figure $3 \mathrm{IL}-8$ levels in human cervical fibroblasts at different times after DHA-S treatment. Open bars, no DHA-S; hatched bars, DHA-S $(0.01 \mathrm{mg} /$ $\mathrm{ml})$; shaded bars, DHA-S $(0.1 \mathrm{mg} / \mathrm{ml})$. ${ }^{*} P<0.01$ compared with respective controls. 


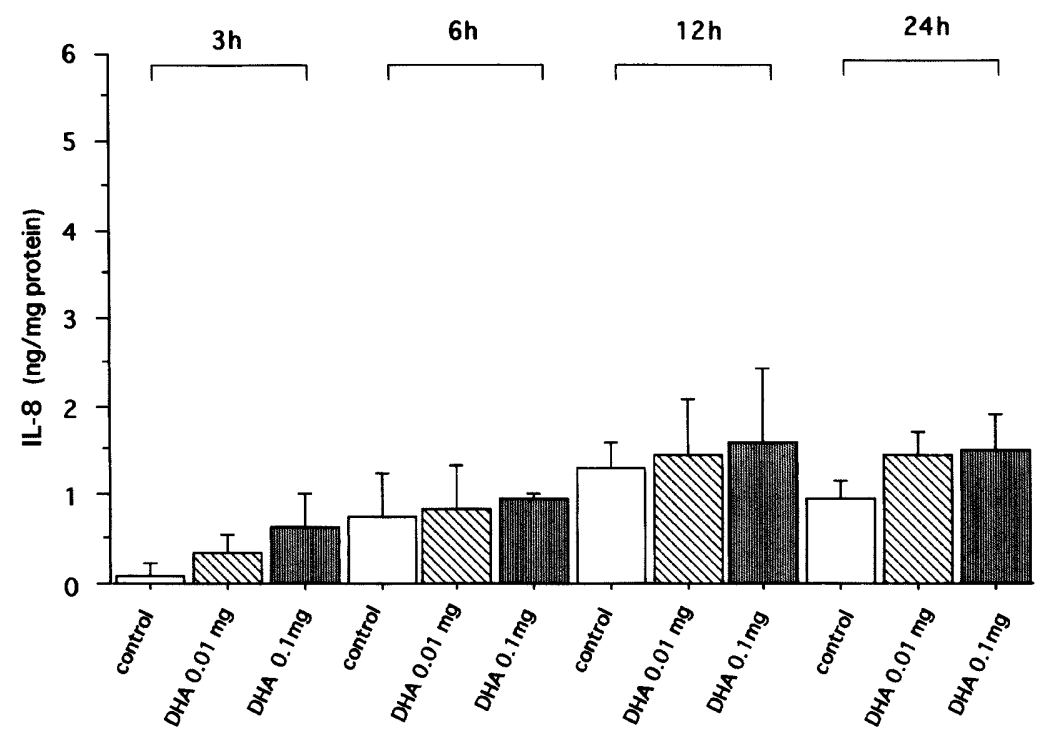

Figure $4 \mathrm{IL}-8$ levels in human cervical fibroblasts at different times after DHA treatment. Open bars, no DHA; hatched bars, DHA $(0.01 \mathrm{mg} / \mathrm{ml})$; shaded bars, DHA $(0.1 \mathrm{mg} / \mathrm{ml})$.
DHA-S and DHA stimulation. As shown in Fig. 1, IL-8 concentrations of the media treated with DHA-S increased time dependently and were already significantly higher than controls after $12 \mathrm{~h}$. On the other hand, the IL-8 concentrations of the media treated with DHA were only slightly increased with time in each group and there were no significant differences between groups (Fig. 2). Intracellular levels of IL-8 increased after DHA-S stimulation (Fig. 3). The intracellular IL-8 levels following treatment with $0.1 \mathrm{mg} / \mathrm{ml}$ DHA-S remained the same from 12 to $24 \mathrm{~h}$. Incubation with DHA had no effect on intracellular IL-8 levels (Fig. 4).

\section{Immunohistochemistry of IL-8 and IL-8 R}

Immunostaining of IL-8 and IL-8 R of cervical tissues in the four patients is summarized in Table 1. Cervical fibroblasts and interstitial tissue of the control samples stained weakly or moderately for IL-8. A significant increase in the density of IL-8 occurred after incubation with various doses of DHA-S. The staining intensity of IL-8 increased following DHA-S incubation in a dose-dependent manner (Fig. 5). On the other hand, the density of IL-8 was not altered by the addition of DHA. The density of IL-8 R was significantly increased when the cervical tissues were incubated with DHA-S (Table 1). The staining intensity of IL-8 R also increased following DHA-S in a dose-dependent manner (Fig. 6). However, the density of IL- $8 \mathrm{R}$ was not altered by the addition of DHA (Fig. 7). IL-8 receptors of the cultured fibroblasts were darkly stained after incubation with DHA-S (Fig. 8).

\section{Discussion}

DHA-S has a great effect on cervical maturity in late pregnancy (24), and is thought to be involved in the regulation of collagenase metabolism in the human cervix at parturition (25). It induces a high concentration and activation of collagenase in the uterine cervix that subsequently results in softening of the cervix (11). However, the exact mechanism of these events is not fully understood. It has been attributed mainly to the direct effect of DHA-S on cervical fibroblasts (25). Recently, we discovered that the combination of IL-8

Table 1 Immunohistochemical findings of IL-8 and IL-8 R of human cervical fibroblasts in cervix at term. Staining intensity of cervical fibroblasts after incubation with DHA-S $(1 \mathrm{mg} / \mathrm{ml})$ or DHA $(1 \mathrm{mg} / \mathrm{ml})$.

\begin{tabular}{|c|c|c|c|c|c|c|}
\hline \multirow[b]{2}{*}{ Patient } & \multicolumn{3}{|c|}{ IL-8 } & \multicolumn{3}{|c|}{ IL-8 R } \\
\hline & DHA-S & $\mathrm{DHA}$ & Control & DHA-S & $\mathrm{DHA}$ & Control \\
\hline 1 & +++ & + & + & +++ & + & + \\
\hline 2 & +++ & ++ & + & +++ & + & + \\
\hline 3 & +++ & + & + & +++ & + & + \\
\hline 4 & +++ & ++ & + & +++ & ++ & + \\
\hline
\end{tabular}

+ , weak; ++ , moderate; +++ , strong. 

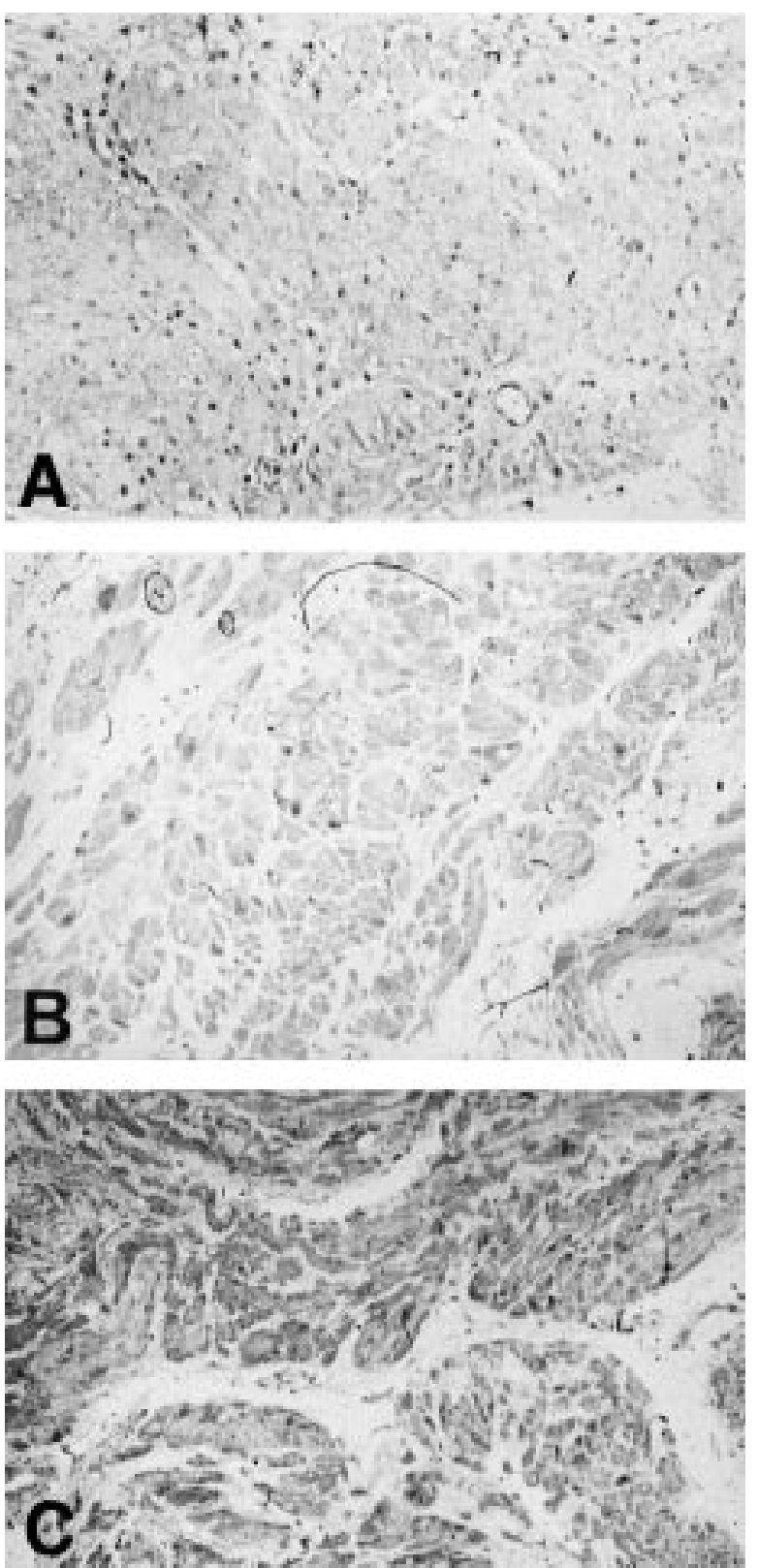

Figure 5 Immunohistochemical study of IL-8 in human cervical tissue at term after treatment with various doses of DHA-S. (A) Control; (B) $0.1 \mathrm{mg} / \mathrm{ml} \mathrm{DHA-S}$; (C) $1 \mathrm{mg} / \mathrm{ml}$ DHA-S.

and DHA-S vaginal suppositories induced a marked cervical maturation in rabbits (26). DHA-S had a synergistic effect on IL-8 action. In our experiments, we found that concentrations of IL- 8 in both the supernatant and cells of cultured cervical fibroblasts were markedly increased after incubation with DHA-S. More importantly, cervical tissues and cervical fibroblasts treated with DHA-S showed an increase in IL-8 and IL- 8 R. These data indicate that the mechanism of action of DHA-S is through the control of IL-8 and IL-8 R. DHA-S may promote the expression of IL- 8 receptors
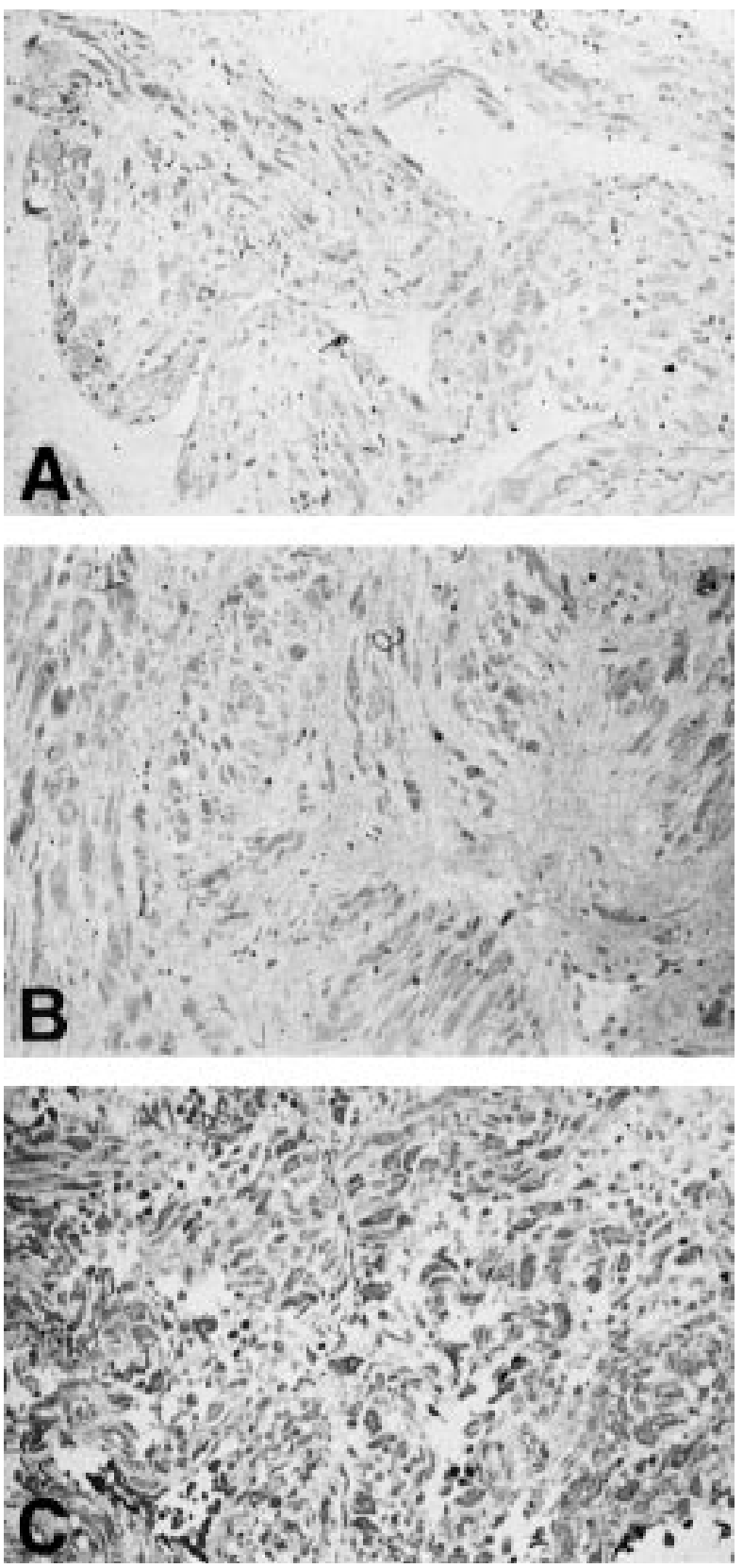

Figure 6 Immunohistochemical study of IL-8 R in human cervical tissue at term after treatment with various doses of DHA-S. (A) Control; (B) $0.1 \mathrm{mg} / \mathrm{ml}$ DHA-S; (C) $1 \mathrm{mg} / \mathrm{ml}$ DHA-S.

in the cervix and increase the affinity of the tissues to bind with IL-8. As a result, the up-regulation of the autocrine system of IL-8 could markedly affect the production and release of IL-8.

Hormonal regulation of IL- 8 by estrogen and progesterone has been studied. Progesterone downregulated IL-8 expression, and estrogen had no effect (23). No hormone has been shown to up-regulate IL-8 production. Serum DHA-S is increased at term 

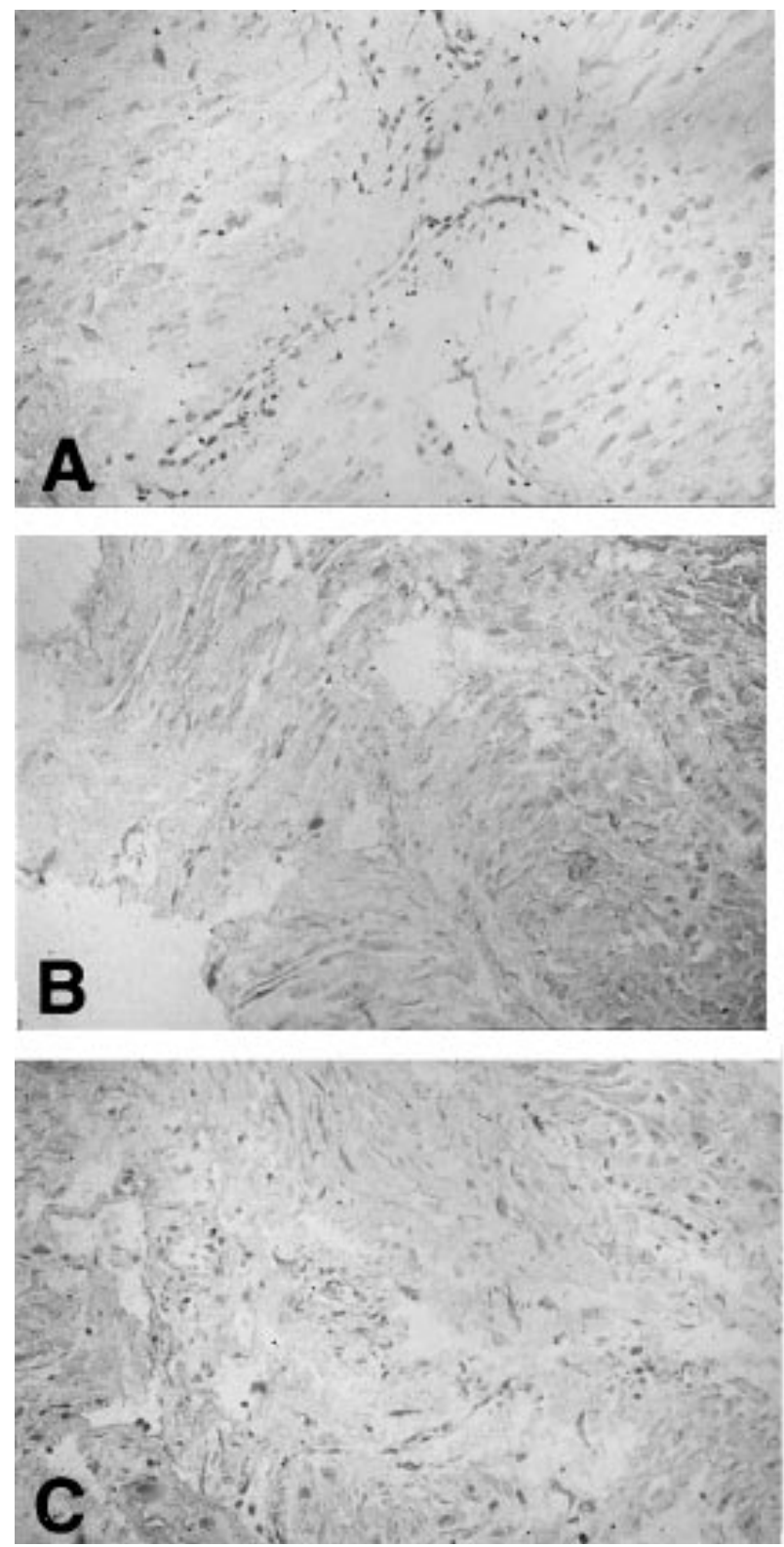

Figure 7 Immunohistochemical study of IL-8 R in human cervical tissue at term after treatment with various doses of DHA. (A) Control; (B) $0.1 \mathrm{mg} / \mathrm{ml} \mathrm{DHA;} \mathrm{(C)} 1 \mathrm{mg} / \mathrm{ml} \mathrm{DHA}$.

pregnancy, whereas the progesterone level is decreased, indicating that DHA-S may affect IL-8 R expression of cervical fibroblasts leading to cervical maturation.

IL- 8 production and expression of IL- 8 is weak in the presence of DHA, but the reason for this is unknown. Sakyo et al. reported that DHA-S increases collagenase activity of cervical fibroblasts in rabbits while DHA does not (25). Androstenediol, which is derived from DHA, increases IL-2 and IL-3 production, but DHA does not (27). The hydrophilic activity of androstenediol is more potent than that of DHA. DHA-S has a hydrophilic
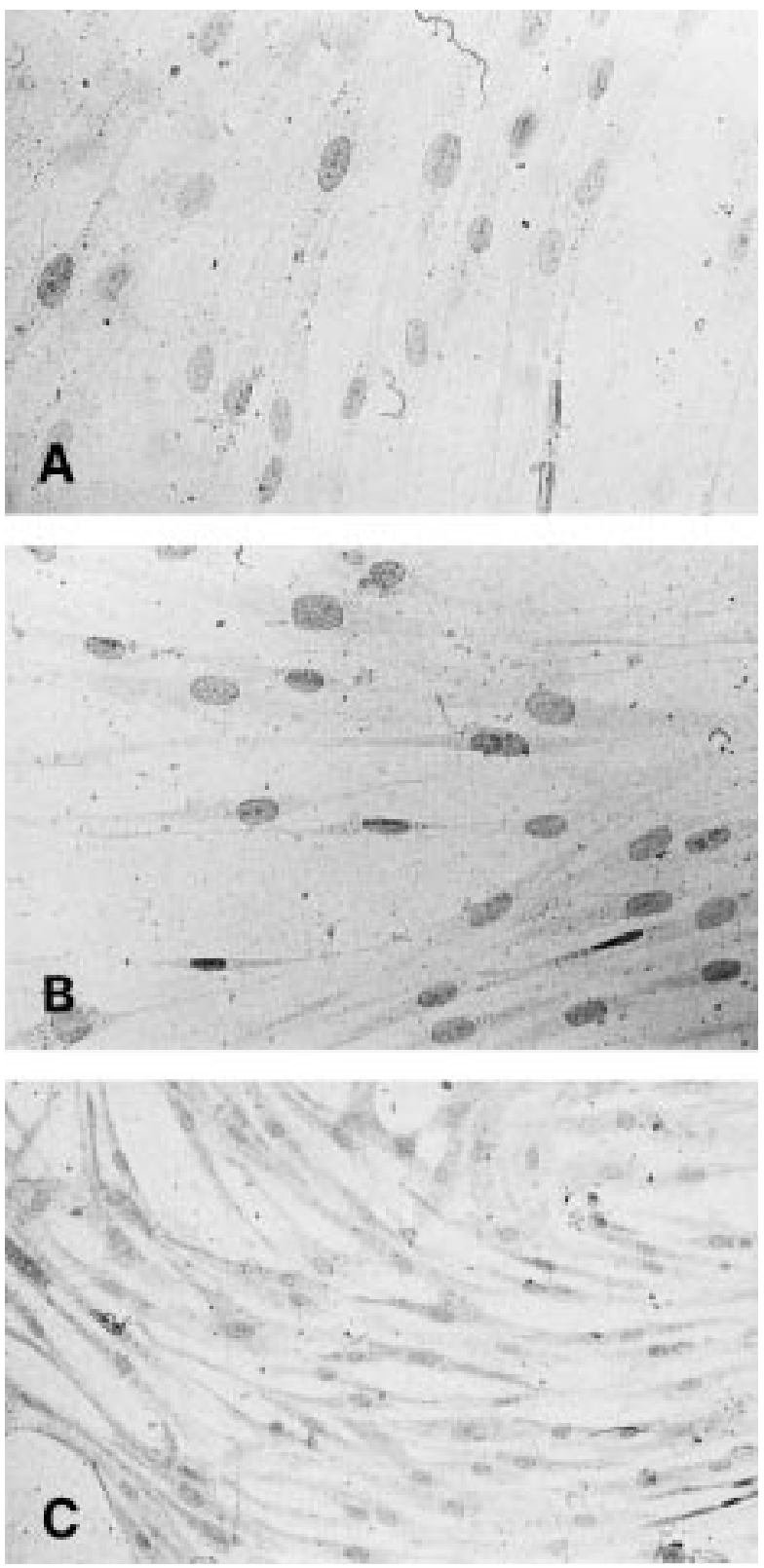

Figure 8 Immunocytochemical study of IL-8 R in cultured human cervical fibroblasts after treatment with various doses of DHA-S. (A) Control; (B) $0.01 \mathrm{mg} / \mathrm{ml} \mathrm{DHA-S}$; (C) $0.1 \mathrm{mg} / \mathrm{ml} \mathrm{DHA-S}$.

and negative charge because of its sulfate residue; this may be related to cell surface binding (28).

Collagenase in cervical fibroblasts, and neutrophils are essential collagenolytic enzymes in cervical maturation. It is known that the production of collagenase from cervical fibroblasts increases through DHA-S stimulation (29). IL-8 stimulates the production of collagenase by cervical fibroblasts (30). The mechanism of action of DHA-S in the production of cervical collagenase may involve the expression of IL-8 R induced by DHA-S. 
IL-8 is a potent chemotactic and activating cytokine for neutrophils. Recently, we found that the local application of exogenous IL-8 induced marked cervical maturation (20). Neutrophil infiltration is important in the process of cervical maturation. Neutrophils infiltrate around the IL-8-bound cells. Collagenolytic activity derived from the infiltrating neutrophils is thought to play the main role in cervical ripening. Infiltration of neutrophils to the cervix may be mediated not only by the level of IL-8 in the tissues, but also by the expression of IL-8 receptors and the affinity of tissues to IL-8. Our previous animal studies revealed that the degree of neutrophil infiltration in subjects treated with DHA-S plus IL-8 is more than that which occurs following treatment with either IL-8 or DHA-S alone $(26,30)$. The expression of IL- 8 R by DHA-S in cervical fibroblasts may participate in effective accumulation of neutrophils around cervical fibroblasts.

In conclusion, control of the autocrine system of IL-8 is regulated by DHA-S, and the system is involved in cervical maturation.

\section{References}

1 Danforth DN. The fibrous nature of the human cervix and its relation to the isthmic segment in gravid and nongravid uteri. American Journal of Obstetrics and Gynecology 194753 541-560.

2 Uldbjerg N, Ulmsten \& Ekman G. The ripening of human cervix in terms of connective tissue biochemistry. Clinical Obstetrics and Gynaecology 198326 14-26.

3 Uldbjerg N, Ekman G, Malmstrom A, Olsson KL \& Ulmsten U. Ripening of the human cervix related to changes in collagen, glycosaminoglycans and collagenolytic activity. American Journal of Obstetrics and Gynecology 1983147 662-666.

4 Kanayama N \& Terao T. The relationship between granulocyte elastase-like activity of cervical mucus and cervical maturation. Acta Obstetrica et Gynaecologica Scandinavica 199170 29-34.

5 Wallis RM \& Hillier K. Regulation of collagen dissolution in human cervix by oestradiol- $17 \beta$ and progesterone. Journal of Reproduction and Fertility 198162 55-61.

6 Sato T, Ito A, Mori Y, Yamashita K, Hayakawa T \& Nagase H. Hormonal regulation of collagenolysis in uterine cervical fibroblasts. Modulation of synthesis of procollagenase, prostromelysin and tissue inhibitor metalloproteinases (TIMP) by progesterone and oestradiol 17 $\beta$. Biochemical Journal 1991275 645-650.

7 Mochizuki M, Honda T, Deguchi M, Morikawa H \& Tojo S. A study of the effect of dehydroepiandrosterone sulfate on so-called cervical ripening. Acta Obstetrica et Gynaecologica Scandinavica 197857 397-401.

8 Tahara R, Yanaihara T, Araki H \& Nakayama T. Steroid concentrations in human cervical tissue in relation to cervical ripening. Acta Obstetrica et Gynaecologica Japonica 198537 1924-1930.

9 Seron-Ferre M, Lawrence CC, Siiteri PK \& Jaffe RB. Steroid production by definitive and fetal zones of the human fetal adrenal gland. Journal of Clinical Endocrinology and Metabolism 197847 603-609.

10 Yoshida K, Tahara R, Nakayama T \& Yanaihara T. Effect of dehydroepiandrosterone sulfate, oestrogens and prostaglandins on collagen metabolism in human cervical tissue in relation to cervical ripening. Journal of Internal Medical Research 199321 26-35.

11 Mochizuki M, Honda T \& Tojo S. Collagenolytic activity and steroid levels after administration of dehydroepiandrosterone sulfate. International Journal of Gynecology and Obstetrics 197816 248-253.
12 Sakyo K, Ito A, Ogawa C \& Mori Y. Hormonal control of collagenase inhibitor production in rabbit uterine cervical fibroblast-like cells. Biochimica et Biophysica Acta 1986883 517-522.

13 Woessner JF Jr. Total latent and active collagenase during the course of postpartum involution of rat uterus. Effect of oestradiol. Biochemical Journal 1979180 95-102.

14 Junqueria LCU, Zugaib M, Montes GS, Toledo OMS, Krisztan RM \& Shigihara KM. Morphological and histochemical evidence for the occurrence of collagenolysis and for the role of neutrophilic polymorphonuclear leukocytes during cervical dilatation. American Journal of Obstetrics and Gynecology 1980138 273-281.

15 Rath W, Osmers R, Adelmann-Gril BC, Stuhlsatz HW, Szeverenyi M \& Kuhn W. Biophysical and biochemical changes of cervical ripening. In Prostaglandins for Cervical Ripening and for Induction of Labour, pp 132-141. Eds C Egarter \& P Husslein. Vienna: Facultas Universitatsverlag, 1981.

16 Murphy G, Reynolds JJ, Bertz U \& Baggiolini M. Partial purification of collagenase and gelatinase from human polymorphonuclear leukocytes. Biochemical Journal 1982203 209-222.

17 Osmers R, Rath W, Grill A, Fittkow C, Kuloczik M, Szevere'nyi M, Tschesche H \& Kuhn W. Origin of cervical collagenase during parturition. American Journal of Obstetrics and Gynecology 1992 166 1455-1460.

18 Baggiolini M \& Sorg C, eds. Interleukin-8 (NAP-1) and Related Chemotactic Cytokines. Basal: Karger, 1991.

19 Peveri P, Walz A, Dewald B \& Baggiolini M. A novel neutrophilactivating factor produced by human mononuclear phagocytes. Journal of Experimental Medicine 1988167 1547-1559.

20 El Maradny EL, Kanayama N, Halim A, Maehara K, Sumimoto K \& Terao T. Interleukin-8 induces cervical ripening in rabbits. American Journal of Obstetrics and Gynecology 1994171 77-83.

21 Uchiyama T, Ito A, Ikesue A, Nakagawa H \& Mori Y. Chemotactic factor in pregnant rabbit uterine cervix. American Journal of Obstetrics and Gynecology 1992167 1417-1422.

22 Barclay CG, Brennand JE, Kelly RW \& Calder AA. Interleukin-8 production by human cervix. American Journal of Obstetrics and Gynecology 1993169 625-632.

23 Ito A, Imada K, Sato T, Kubo T, Matsushima K \& Mori Y. Suppression of interleukin 8 production by progesterone in rabbit uterine cervix. Biochemical Journal 1994301 183-186.

24 Mochizuki M \& Maruo T. Effect of dehydroepiandrosterone sulfate on uterine cervical ripening in late pregnancy. Acta Physiologica Hungarica 198565 267-274.

25 Sakyo K, Ito A, Hirakawa S \& Mori Y. Specific binding of dehydroepiandrosterone sulfate to cytoplasmic macromolecule in human fetal membrane. Chemical and Pharmaceutical Bulletin $1986342126-2132$.

26 El Maradny EL, Kanayama N, Maehara K, Kobayashi T \& Terao T. Dehydroepiandrosterone sulfate potentiates the effect of interleukin-8 on the cervix. Gynecologic and Obstetric Investigation 199642 191-195.

27 Loria RM, Padgett DA \& Huynh PN. Regulation of the immune response by dehydroepiandrosterone and its metabolites. Journal of Endocrinology 1996150 S209-S220.

28 Saitoh H, Hirato K, Tahara R, Ogawa K, Noguchi Y, Yanaihara T \& Nakayama T. Enhancement of human amniotic phospholipase A2 activity by steroid-sulphate derived from feto-placental unit. Acta Endocrinologica 1984107 420-424.

29 Sakyo K, Ito A \& Mori Y. Effects of dehydroepiandrosterone sulfate on production of collagenase and gelatinolytic metalloproteinase by rabbit uterine cervical cells in primary cultures. Journal of Pharmacobio-Dynamics $19869276-286$.

30 El Maradny EL, Kanayama N, Halim A, Maehara K \& Terao T. Biochemical changes in the cervical tissue of rabbit induced by interleukin-8, interleukin $1 \beta$, dehydroepiandrosterone sulfate and prostaglandin $\mathrm{E}_{2}$ : a comparative study. Human Reproduction 199611 1099-1104.

Received 15 September 1997

Accepted 13 January 1998 